\title{
Chapter 8 \\ Acts of Vandalism and Fear in Neighbourhoods: Do They Affect Housing Prices?
}

\author{
Vania Ceccato and Mats Wilhelmsson
}

\begin{abstract}
Ampliatus Pedania is a thief. This was a graffiti from ancient Rome, where the act of graffiting was considered vandalism to properties.
\end{abstract}

- Ampliatus Pedania est fur

\subsection{Introduction}

People often value the safety of a neighbourhood highly when they are choosing a place to live. In Sweden, people participating in housing and neighbourhood quality surveys declare safety as one of the most important qualities of a residential area (Magnusson and Berger 1996; Fransson et al. 2002). The mechanisms linking safety (or lack of it) and housing preferences are not very well understood, but evidence shows that they are mediated by how crime, disorder and fear of crime affect neighbourhoods (Shaw and McKay 1942; Wilson and Kelling 1982; Skogan 1990; Taylor 1995; Garcia et al. 2007) and, indirectly, property prices (Thaler 1978; Buck et al. 1991; Bowes and Ihlanfeldt 2001; Gibbons 2004; Ceccato and Wilhemsson 2011).

Signs of physical deterioration, such as vandalism, are thought to be more important determinants of fear of crime than the actual incidence of crime in neighbourhoods. Wilson and Kelling (1982) suggest that acts of vandalism and public disorder function as symbols of the extent to which a neighbourhood is in decline. As Skogan (1996) suggests, this is not only because signs of physical deterioration

\footnotetext{
V. Ceccato $(\bowtie)$

School of Architecture and the Built Environment, Royal Institute of Technology (KTH), Drottning Kristinasväg 30, 10044 Stockholm, Sweden

e-mail: vania.ceccato@abe.kth.se

M. Wilhelmsson

Centre for Banking and Finance - Cefin, School of Architecture and the Built Environment, Brinellvägen 1, 10044 Stockholm, Sweden

e-mail: mats.wilhelmsson@abe.kth.se
} 
are often visible but also because they are able to capture a much broader range of problems and are therefore more informative to residents than official crime statistics. The neighbourhood decline may translate into an increasing desire to move, weaker attachments of residents to the area and lower house values. Those who can afford, may be willing to pay more for living in neighbourhoods perceived as safe. Alternatively, those who cannot (or do not want to) pay extra for a property expect actual discounts for purchasing in neighbourhoods with higher crime rates or which are perceived as unsafe.

In this chapter, we assess whether lack of safety in neighbourhoods (potentially triggered by vandalism and/or fear of crime) affects property prices. Hedonic pricing modelling is employed to estimate the impact of vandalism and fear of places in the neighbourhood, controlling for other factors (property-related characteristics, place features, neighbourhood characteristics). The study is based on apartment prices using data of about 9,000 apartment sales in Stockholm, the capital of Sweden, in 2008.

Geographical information system (GIS) was used to make possible the inclusion of a series of variables that are often neglected in studies of this type, such as proximity to highways, water and underground stations. GIS also allows the incorporation of information from both a specific neighbourhood as well as its surrounding areas. This is important because if a neighbourhood is safe (low crime and fear of crime) but is surrounded by areas with high crime, disorder and high levels of fear of crime, then criminogenic conditions in that area may be underestimated because of the high levels of crime in neighbouring zones. GIS and spatial statistics techniques are used to tackle this problem, so the neighbourhood structure is added to the model to capture crime conditions at each unit of analysis but also in its neighbouring units.

This chapter is organised as follows. The next section discusses the potential impact that crime, and particularly acts of vandalism, has on neighbourhoods. This is followed by an analysis of how neighbourhoods are affected by fear of crime. Both sections provide the set of hypotheses of study. In Sect. 8.3, the case study of Stockholm is framed. The methodology is presented in Sect. 8.4, followed by results in Sect. 8.5. Conclusions and recommendation for future studies are presented in Sect. 8.6.

\subsection{Vandalism, Fear of Crime, Neighbourhood Quality and Housing Market}

Vandalism is a criminal offence involving damage to or defacing of property belonging to another person or to the public. The Swedish Legal Penal Code defines a vandal as any 'person who destroys or damages property, real or moveable, to the detriment of another's right thereto' (Ministry of Justice 1999: 36). Vandalism is often directed at unclaimed or impersonal public spaces (e.g. squares, bus stops) rather than at private homes. However, no one denies its effects on the urban landscape and people's attachment to places and place attractiveness. The underlying 
reasons for vandalism and where it occurs vary. As suggested by Skogan (1990), vandalism may be a form of entertainment for groups of young people; it may be a symbolic act or a demarcation of a group's territory, or may even be the way a group expresses its revolt or frustration towards a situation or an expression of intergenerational conflict. Cohen (1973) distinguished between vindictive vandalism (a form of vengeance), play vandalism (breaking windows, graffiti), tactical vandalism (sabotage in the workplace) and malicious vandalism (out of boredom or frustration).

Levels of acts of vandalism recorded by the police vary across neighbourhoods and places in the city. Its reporting depends on individuals' willing to report to the police where these events take place but also whether acts are defined as crime by the law (Ceccato and Haining 2005). Vandalism and other signs of physical deterioration are often taken as signs of other social problems, which in turn lead to fear (Wilson and Kelling 1982). Fear results from the perception that informal and formal social controls in the area are weak. Living in a place where public disorder (e.g. abandoned buildings, vandalism, drug use and loitering teenagers) is part of the daily routine, affects one's perceived safety (Lewis and Maxfield 1980). As McCrea et al. (2005) suggest, individuals can experience fear of crime simply by observing incivilities and perceiving a relationship between disorder and an increased risk of crime. Disorder and physical deterioration also promote the notion that no one is in control - a development that goes hand in hand with high levels of community social disorganisation (Shaw and McKay 1942; Kornhauser 1978) and low collective efficacy (Sampson et al. 1997; Sampson and Raudenbush 1999). More recent research shows, for instance, that fear may also be triggered by certain community policing practices, particularly those perceived as repressive (e.g. Scheider et al. 2003).

But what is fear of crime? Ferraro (1995: 8) defines it as 'an emotional reaction of dread or anxiety to crime or symbols that a person associates with crime'. Fear of crime does not happen in a vacuum. As defined by Wyant (2008: 40), it is a 'product of individual-level processes, many related to perceptions of personal vulnerability to crime, and of ecological (e.g. neighbourhood) setting conditions and dynamics'. How a person fears is therefore dependent on the individual's characteristics, such as physical abilities, age, gender, socio-economic status, ethnic background and previous personal experiences (Skogan and Maxfield 1981; Hale 1996; Will and Mcgrath 1995; Pain 2000). According to McCrea et al. (2005), the individual dimension of fear is related to the vulnerability hypothesis where those perceiving themselves as vulnerable are likely to fear crime. Fear is also dependent on an individual's quotidian environment and lifestyles (Eschholz 1997; Zelinka and Brennan 2001), but also on more general aspects in society, such as political climate, that mediate fear and risk in modern societies (see, e.g. Murray 2007; Los 2002). In addition, fear is influenced by other more multi-scale factors (national, global) that reach individuals in their daily life through, for instance, the media (Pain 2009; Day 2009).

At the individual level, fear affects behaviour, becoming a barrier to individuals' physical activity and good health (Miles and Panton 2006; Eyler et al. 1998; Sundquist et al. 2006). At the collective level, fear creates borders between social 
groups, cultures and neighbourhoods (Caldeira 2000; Landman 2005), while others argue that the opposite is true: isolation also creates fear and suspicion (e.g. Pain 2010). Decreased mobility harms social interactions, which makes people even further isolated. Fear therefore affects the health of the community: people's mutual trust and social cohesion (Riger et al. 1981; Garcia et al. 2007).

Not surprisingly, individuals start expressing evidence of functional fear (Jackson and Gray 2010) by trying to prevent something bad from happening. According to Foster and Giles-Corti (2008), constraining behaviour might be adopted, so exposure to potentially dangerous situations is minimised by staying away from certain places or avoiding long walks (Ross 1993). For those who are willing to pay, taking security precautions (Skogan and Maxfield 1981) and choosing a new place to live, away from the problem, are potential alternatives. Those who can afford would certainly pay extra to avoid living in fear, so they would buy a property in a neighbourhood with low levels of disorder, crime and fear.

The truth is that whether fear of crime impacts on people's willingness to pay for a property is still an issue little investigated in the international literature (but see, e.g. Linden and Rockoff 2006; Pope 2008). In Pope (2008), for instance, fear was measured by the potential danger of having a sex offender's residence in the neighbourhood. Results indicate that after a sex offender moves into a neighbourhood, nearby housing prices fall by $2.3 \%$. However, once the sex offender moves out, housing prices appear to rebound immediately.

More often, evidence is found in the international literature for the effect of crime on property values. In the USA, evidence from the last three decades confirms that crime has a significant impact on house prices (Thaler 1978; Hellman and Naroff 1979; Rizzo 1979; Dubin and Goodman 1982; Clark and Cosgrove 1990; Tita et al. 2006; Munroe 2007). Sometimes, its effect is not consistent across all geographic areas. For instance, Lynch and Rasmussen (2001) weighed the seriousness of offences by the cost of crime to victims. Findings showed that, although cost of crime had no impact on house prices overall, properties were cheaper in high-crime areas. Interestingly, housing prices are affected not only by local crime but also by crime rates in neighbouring zones (Gibbons 2004).

In the UK, the effect of crime on property prices does not seem to be the same across crime types. Gibbons' (2004) study showed that only criminal damage affected housing prices negatively. One explanation for this is that vandalism, graffiti and other forms of criminal damage motivate fear of crime in the community and may be taken as signals or symptoms of community instability and neighbourhood deterioration in general, pulling housing prices down.

In Sweden, Ceccato and Wilhelmsson (2011) found that when crime rates were broken down by types, they had a negative effect on apartment prices after controlling for property and neighbourhood characteristics in Stockholm. Vandalism had a statically greater effect on apartment prices, but residential burglary showed a more robust model and a more direct impact on property prices than vandalism. Results also showed that apartment prices in a specific area were strongly affected by crime in its neighbouring zones, and its impact was not homogenous across space (e.g. North and South Stockholm). The study makes no reference to the effect of fear on housing prices. 
Following the evidence from previous research on crime and fear of crime, the following hypotheses are tested in this study:

1. Vandalism negatively impacts apartment prices after controlling for attributes of the property and neighbourhood characteristics.

2. The price of an apartment is dependent on the vandalism rates at its location as well as the crime rates in the surrounding areas (extending Ceccato and Wilhelmsson 2011).

3. Areas with depleted perceived safety are also the ones with lower housing prices after controlling for other factors (property-related characteristics, place features, neighbourhood characteristics).

4. The price of an apartment is dependent on the fear of places in the neighbourhood as well as fear of places perceived in the surrounding areas.

5. Fear of crime affects apartment prices even after signs of physical damage (vandalism) of an area are controlled for.

\subsection{The Case Study}

Stockholm is a safe city. The 2008 safety survey (based on 20,000 respondents) shows that the majority of the adult population in Stockholm city does not worry about crime even though crime events tend to happen more often in Stockholm city than in the rest of the country (total recorded crime was 115 per 1,000 inhabitants, whilst the rate for the whole country was 71 per 1,000 inhabitants) (Stockholm municipality 2008). These results are in line with the 2,000 victim survey performed for the whole of Sweden, establishing the country as one of the safest in Europe (Del Frate and Van Kesteren 2004). Stockholm is the capital and the largest city of Sweden. The city of Stockholm had over 840,000 inhabitants in 2010, whilst the Greater Stockholm area had just over two million inhabitants. The casestudy area is limited to the city of Stockholm, which means the inner-city area and those suburbs as shown in Fig. 8.2.

Stockholm is part of an archipelago, and therefore, water occupies a large part of the urban landscape since the city is spread over a set of islands on the southeast coast of Sweden. This feature means that some condominiums and houses have the privilege of facing beautiful sceneries, towards water and urban parks. The islands are well connected by roads and an efficient public transportation system, comprised of buses, Stockholm Metro, rail systems and commuting trains. The main public transport junction is located in the central business district (CBD) area, in the central area of the inner city. All underground lines pass through the central station, which is the main railway station of the capital, making this area a place where many travellers and workers pass daily. This place is an area of population convergence and becomes both a crime generator and attractor (Brantingham and Brantingham 1995). The central square, and one of the main meeting points of the city, is a relatively high criminogenic area, where violence- and drug-related 
offences tend to be concentrated (Ceccato et al. 2002). Overall, large parts of Stockholm's inner city are residential, where citizens enjoy high housing standards. Although other types of housing tenancy can also be found in the inner-city areas of Stockholm, privately or cooperatively owned apartments dominate. The last two decades have been characterised by increasing population density of the central areas, some being eco-housing developments, which are very attractive to young families and highly valued in the market.

Since the early twentieth century, modernism characterised the development of the city as it grew, and new residential areas were added to the growth. Some of these areas were valued highly in the housing market, especially those developments following the underground system. As suggested in Ceccato and Wilhelmsson (2011: 9), the industrialised and mass-produced blocks of flats built in the 1960s and 1970s do not perform equally well in the market: low prices are often linked to poor architecture, lack of amenities and social problems, such as crime, public disorder and fear of crime.

Police statistics show that total offence rates in Stockholm city increased $10 \%$ between 1999 and 2009. Of greater concern is the fact that this increase is concentrated in some areas. The 2008 victimisation survey shows areas where perceived safety is lower than the rest of the city (Stockholm municipality 2008).

Many cases of vandalism are not reported to the police, which makes it difficult to gain an accurate idea of its proportions. What is known is that vandalism is typically a youth crime: among suspects in 2007, half were between 15 and 20 years old. In 1999, vandalism constituted $10 \%$ of all police statistics in Stockholm city, whilst 10 years later, it reached 15\%. According to BR rådet - the Swedish National Council for Crime Prevention) (2010), one of the reasons for the increase is that people are more willing to report graffiti and criminal damage than they were in the past. People have become less tolerant of these types of acts, but it has also become easier to identify offenders. New techniques of identification are likely to have contributed to the increase in reports. Since 2007, personnel working in Stockholm's public transportation system started taking photographs and reporting cases of graffiti they encountered - material that can be used in court to help identify suspects. Figure 8.1 shows vandalism rates in Stockholm city between 1999 and 2009.

Vandalism rates vary across Stockholm (Fig. 8.2a). Land-use composition and a city's physical and socio-economic structure play important roles in the distribution of vandalism. Vandalism is concentrated in the central areas of cities where there is public entertainment, but also in the outskirts, often in unstable residential areas (Wikström 1991; Torstensson 1994; Ceccato et al. 2002). However, reporting rates for vandalism are likely to be underestimated in less cohesive areas, since people do not take the trouble to report or might even be afraid to do so. Inaccuracy can affect the data quality of police statistics, which arises during the process of recording and geocoding it (Hirschfield and Bowers 1997; Ceccato and Haining 2005) but is also related to the offenders' mobility. Vandalism occurs not only where offenders live, but follows their whereabouts, showing elements of a spatially contagious process, spilling over into nearby areas (Ceccato and Haining 2005). 


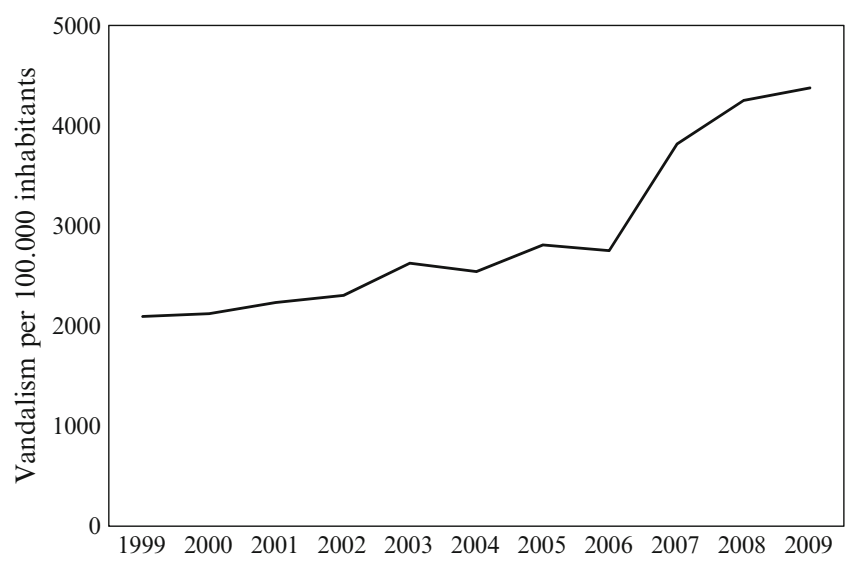

Fig. 8.1 Vandalism rates in Stockholm city, 1999-2009 (Data source: National Council for Crime Prevention 2010)

Despite an increase in police-recorded vandalism cases in Stockholm, most people do not experience vandalism as an increasing problem in their neighbourhood, according to the most recent Standard of Living Survey (SCB 2008). This does not mean, however, that vandalism has no impact on perceived safety. The way perceived safety is measured is often not problem-free, since, as suggested by Lagrange and Ferraro (1989: 698), fear of crime measures are not necessarily a measure of fear, but rather an indication of the risk of being victimised.

Fear of places in the neighbourhood is used in this study as a proxy of local levels of fear of crime. Figure 8.2 illustrates an indication of the variability of perceived safety in Stockholm neighbourhoods. Dark shades in Fig. 8.2 show higher percentages of respondents who answered to the following question:

Do you feel sometimes afraid of being in certain places in your neighbourhood (bostadshus och närhet) because you could become a victim of crime? Yes, in one or several places.

\subsection{Modelling Apartment Prices}

Traditionally, hedonic price models are used to analyse property values. They are based on the principle that goods are not homogenous and differ in numerous attributes, which can be implicitly revealed by observed differences in prices (Rosen 1974). In the case of housing, preferences for various attributes are revealed through the price one implicitly pays for these attributes, which can be expressed as:

$$
y=\beta x+\varepsilon
$$

where $y$ is a vector of observations on the sales price, $x$ is a matrix of observations on the property attributes, $\beta$ is the associated vector of regression coefficients (the marginal implicit price of each attribute) and $\varepsilon$ is a vector of random error terms. 

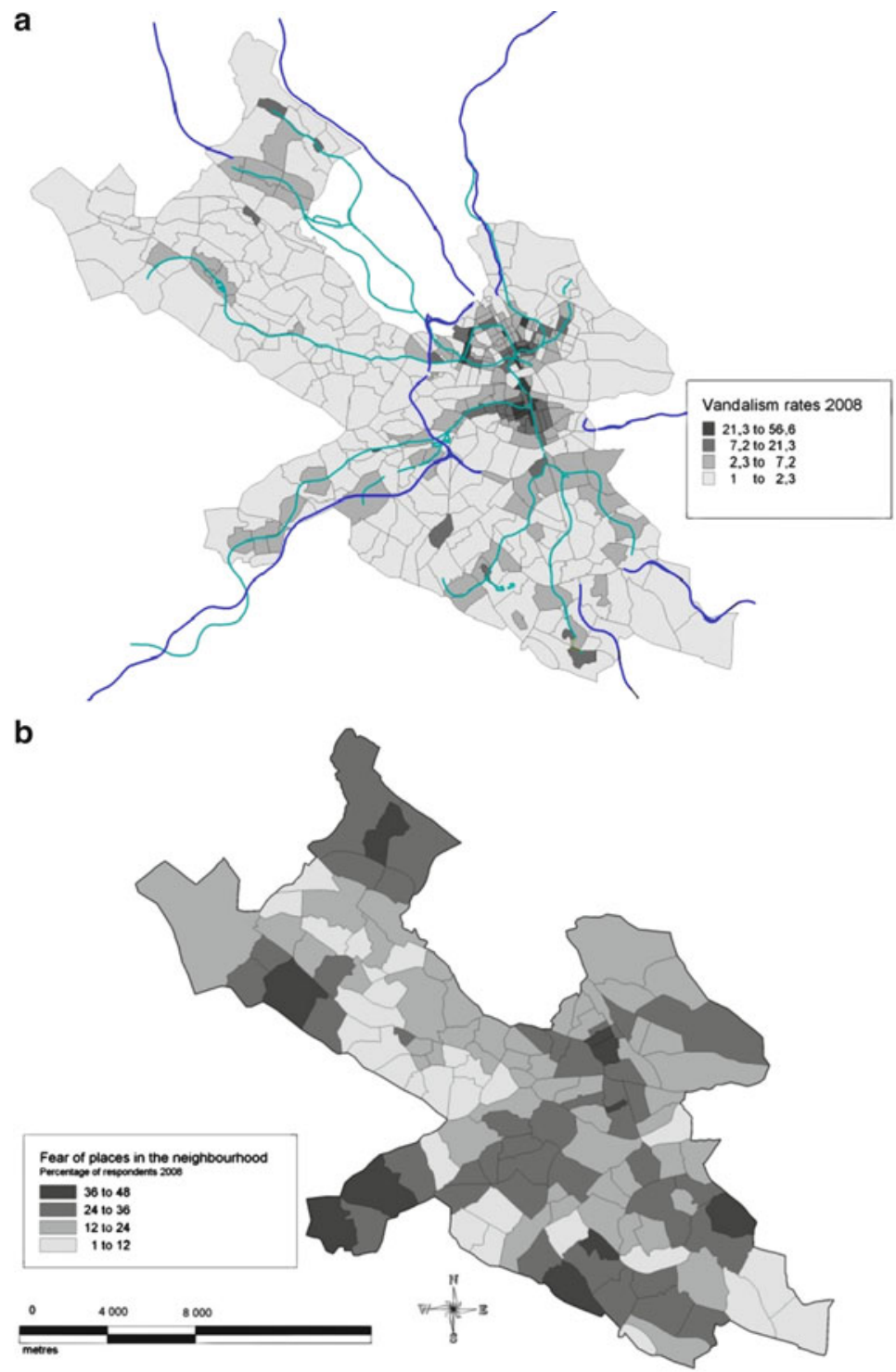

Fig. 8.2 (a) Vandalism per area (square metre) in Stockholm, 2008 (Legend: Natural break). (b) Feeling unsafe in the neighbourhood (\% of respondents), Stockholm's 2008 safety survey (Legend: Equal range)

According to Wilhelmsson (2002), where housing prices are concerned, the choice of attributes often involves characteristics of the property, characteristics of the property location and features of the neighbourhood.

There is no consensus on which set of relevant characteristics of the city structure and environments should be selected for price determination. They are often related to different environments to which the property is exposed and how 
these may add to or subtract from the value of the property. It is difficult, however, to control for all possible relevant neighbourhood factors (Can 1990). An apartment facing a lake may add value to a property, whilst one close to an industrial site or close to a sex offender residence may have its price discounted (see, e.g. Larsen et al. 2003; Linden and Rockoff 2006; Karlsson 2008; Kryvobokov and Wilhelmsson 2007).

The estimation of the hedonic equation is based on cross-sectional data that include arm's-length transactions of condominiums in Stockholm. The data cover a time span from January 2008 to December 2008 and consist of 9,622 transactions of condominiums. The data source is Broker Statistics, a real-estate broker association that covers around $70-80 \%$ of all broker transactions in Stockholm. The database contains property address, area code, parish code, selling price, living area, year of construction, presence of balcony and elevator, price per square metre, date of contract, condominium fee, number of rooms, date of disposal, number of the floor of the specific apartment, total number of floors, post code and $x, y$ coordinates. For simplicity of the analysis, $7 \%$ of multiple addresses were excluded: only one transaction for $x, y$ coordinates remained in the database. The final database consisted of 8,938 transactions of condominiums. The $x, y$ coordinates of each apartment were transformed into Dirichlet polygons using GIS and then imported into GeoDa 0.9.5-1 (Anselin 2003). This was necessary to be able to produce a weight matrix (Queen's matrix is set to 1 if the pair of cells share a common edge or vertex and 0 otherwise, first-order criterion) and generate autocorrelation diagnostics on the residuals of the OLS regression. If spatial autocorrelation on residuals is present, it violates the ordinary least squares assumption that the error terms are uncorrelated and other models have to be tested.

In order to estimate the impact of vandalism and fear of crime on housing values, other conditions that, together with crime, contribute to lowering property prices must be taken into account; otherwise, such an impact may be overstated (Cohen 1990). For instance, neighbourhoods with high crime may also experience fewer environmental amenities (e.g. proximity to parks, lakes, playgrounds and good schools), isolation (poor accessibility), proximity to major highways and transport nodes (with noise and air pollution) and industrial land use or commercial/ entertainment areas (e.g. close to bars, restaurants, pubs). Buffer analysis was used in GIS to indicate the apartments that were more or less exposed to different types of environmental characteristics, such as property facing water, distance to roads, main motorways, metro and train stations. Instead of defining a fixed distance, different distance bands were tested. Figure 8.3 illustrates sold apartments within 100,300 and $500 \mathrm{~m}$ from the main motorway (See electronic version for colour figures).

Fear of crime by area (stadsdel) was linked to the $x, y$ coordinates of each apartment sale. First, the map of Stockholm city with 132 units was layered over the apartments' $x, y$ coordinates. Then, using standard 'table join' function in GIS, all sales within the boundaries of a polygon (stadsdel) were associated with its respective percentage of 'fear of places' in that area. The same procedure was performed to link vandalism crime rates to the apartment coordinates. The only 


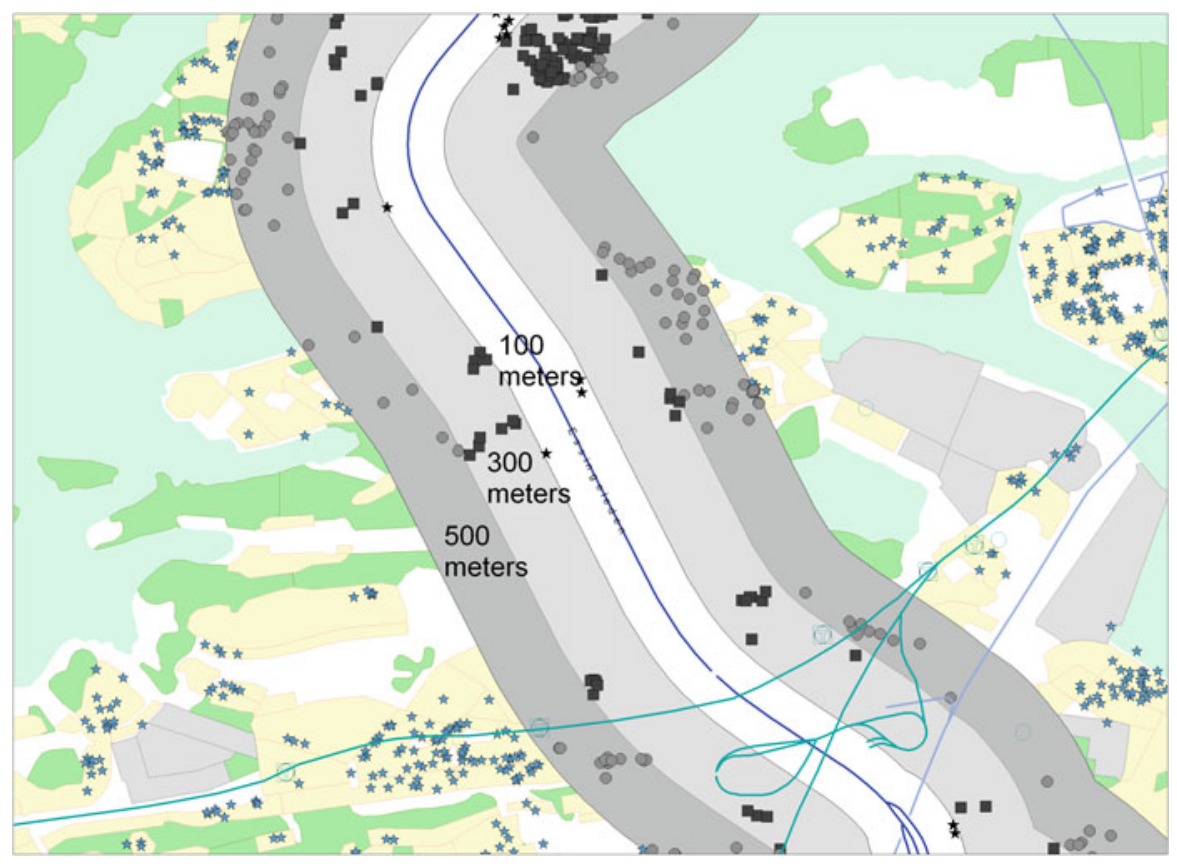

Fig. 8.3 Sold apartments in relation to main motorway, buffer of $100 \mathrm{~m}$ (stars), $300 \mathrm{~m}$ (squares) and $500 \mathrm{~m}$ (circles) (See electronic version for colour figures)

difference was that crime rates were provided by Stockholm Police by small unit areas (basomrade), which is the smallest geographical unit one can obtain (statistical data in Sweden) in a total of 408 units. For detailed characteristics of the datasets used in this study, see Appendix 1. The average price of an apartment is SEK 2.3 million, and the variation around the average price is substantial. The typical apartment in the sample is 50 years old, with approximately 62 square metres of living space over 2.3 rooms. Only $2 \%$ of the sample is newly built apartments. More than half of the apartments are located in buildings built between 1900 and 1945. The fee paid for maintenance is about SEK 3,000 per month. Approximately 20\% are located on the first floor and around $25 \%$ on the top floor. Almost $11 \%$ of the apartments have an elevator, and more than half of the apartments are located in properties with an elevator.

Prices of apartments are expected to be affected by both crime and fear of crime at their location and their neighbourhood but also by their immediate surrounding areas. This is particularly important since offenders' behaviour is often motivated by local factors, but sometimes shows elements of a spatially contagious process, spilling over into nearby areas. The same reasoning can also be tested for fear of crime. An apartment located in an area showing low levels of fear of crime but surrounded by areas with high fear of crime should be receiving a mixed effect from low to high fear of crime conditions. The effect of crime/fear of crime from neighbouring zones on a specific apartment can be measured by incorporating spatially lagged variables of offence rates into the model, so the variable can be tested for a spill-over effect. Spatially lagged variables are weighted averages of the 
values for neighbouring locations, as specified by a spatial weights matrix - in this case, a queen-based contiguity spatial weights matrix. The lag variables were regarded as exogenous covariates and were created based on the natural log of the original crime rate/fear of crime variable.

Even if all possible covariates are added to the model, there is no guarantee that all relevant independent variables are included in the model. Hence, the exclusion of relevant variables (when multicollinearity is present) will not only create omitted variable bias, but also endogeneity among the independent variables. To address endogeneity bias, an instrument crime variable was created by purging its correlation with unobservable influences on apartment prices, using variables that are correlated with crime but not with apartment prices. According to Tita et al. (2006), murder is an ideal instrument. The validity of this instrument depends on whether murder is correlated to crime, but not prices. If there is a strong relationship between murder and crime rate, it is considered to be a strong instrument. Bound et al. (1995) suggested the use of a $t$-test if only one instrument variable is used to check for the validity of the instrument variable. These tests show that in the case of Stockholm, the homicide rate is a strong covariate to predict crime rates ( $t$-test $\left.25.75^{1}\right)$ but a poor independent variable when regressed against apartment prices ( $t$-test -1.54$)$, which provides evidence of a good instrument variable.

When spatial autocorrelation of the residuals is present, the common practice is to fit either a lagged response model or a spatial error model to try to handle the problem of autocorrelation in the residuals (for details, see Ceccato and Haining 2005). Findings are presented in Sect. 8.5.

\subsection{Results and Discussion}

We have estimated a hedonic price equation where the dependent variable is equal to the natural logarithm of apartment prices. As independent variables, we have used apartment and property attributes as well as neighbourhood attributes together with an indicator of vandalism in the area and in the neighbouring areas. The results are presented in Tables 8.1. and 8.2.

The explanatory power $\left(R^{2}\right)$ of the model is relatively high. Around $77 \%$ of the variation in price can be explained by the independent variables in the OLS model, and the results from the error model indicate that more than $88 \%$ of the variation in apartment prices can be explained by the included hedonic attributes. According to the model diagnostics, the spatial error model with instruments seems to show results that are more robust than the lagged response model. Therefore, we shall not discuss the lag model results further.

\footnotetext{
${ }^{1}$ The $t$-test is a test of whether the estimated parameter is significantly different from zero. If there is a significant difference from zero (the absolute value is above around 2), the explanatory variable is related to the dependent variable. In most cases, we would like to reject the hypothesis as the null hypothesis indicates that the parameter is equal to zero (no effect).
} 
Table 8.1 $\mathrm{Y}=\log$ apartment prices - OLS and spatial error models with instrument variables

\begin{tabular}{lll}
\hline & \multicolumn{2}{l}{ Vandalism coefficient } \\
\cline { 2 - 3 } & OLS & Error \\
\hline Vandalism & -.0340 & -.0058 \\
& $(-2.27)$ & $(-2.80)$ \\
W_Vandalism & -0.184 & .0035 \\
& $(-4.83)$ & $(4.32)$ \\
R square & .7662 & .8854 \\
Moran's I on residuals & 0.50 & \\
\hline
\end{tabular}

Note: $t$ - and $z$-values with brackets, respectively. Parameter estimates concerning housing attributes, land-use characteristics and time dummies are not shown in the table (see Appendix 1 for all the independent variables)

According to the OLS and the spatial error model, all estimated parameters concerning property and apartment attributes are in the anticipated direction and are of reasonable magnitude. Both models showed that vandalism rates impact negatively on apartment prices. However, the implicit price differs considerably. According to the error model, if the vandalism rate in the area increased by $1 \%$, apartment prices would be expected to fall by $0.0058 \%$. The OLS model showed a stronger effect of vandalism on prices (a fall of $0.034 \%$ ). The difference between the estimates of the implicit prices could be that the spatial structure we implement in the error model is highly correlated with the variable vandalism rate. That is, we have some kind of multicollinearity between the included explanatory variable vandalism and the spatial structure. Hence, even if the $R^{2}$ indicates that the error model is superior to the OLS model in explaining apartment prices, it may not be the best model for estimating the implicit price of vandalism (see also discussion in Wilhelmsson 2002; Ceccato and Wilhelmsson 2011).

Interestingly, the results also indicated that what happens in the surrounding neighbourhoods does have an effect on the price of a specific apartment at a certain location. It is uncertain, however, how vandalism levels impact prices. The OLS model, for instance, shows evidence that vandalism negatively affects housing values, both in the neighbourhood as well as in the neighbouring area, whilst the error model shows evidence that vandalism in surrounding neighbourhoods actually increases property values at a certain location. Buyers may interpret vandalism in nearby areas as a quality they would rather avoid but which, by comparison, makes their own neighbourhood look more attractive (an 'at least we have it better than them' effect). Regardless of the nearby neighbourhood effect, vandalism at a specific neighbourhood does impact negatively on apartment prices. These results corroborate findings found in the recent international literature, for instance, in the case of vandalism in London (Gibbons 2004).

Vandalism impacts an area on different ways. Previous literature in urban criminology illustrates different dynamics behind property value depreciation through the interpretation of vandalism and other incivilities. Buyers read into the presence of disorder, vandalism and incivilities that residents and authorities have lost control of the area. This explanation is plausible but cannot be tested here since the evidence is cross-sectional. It would be necessary to model crime differences as an indication of 


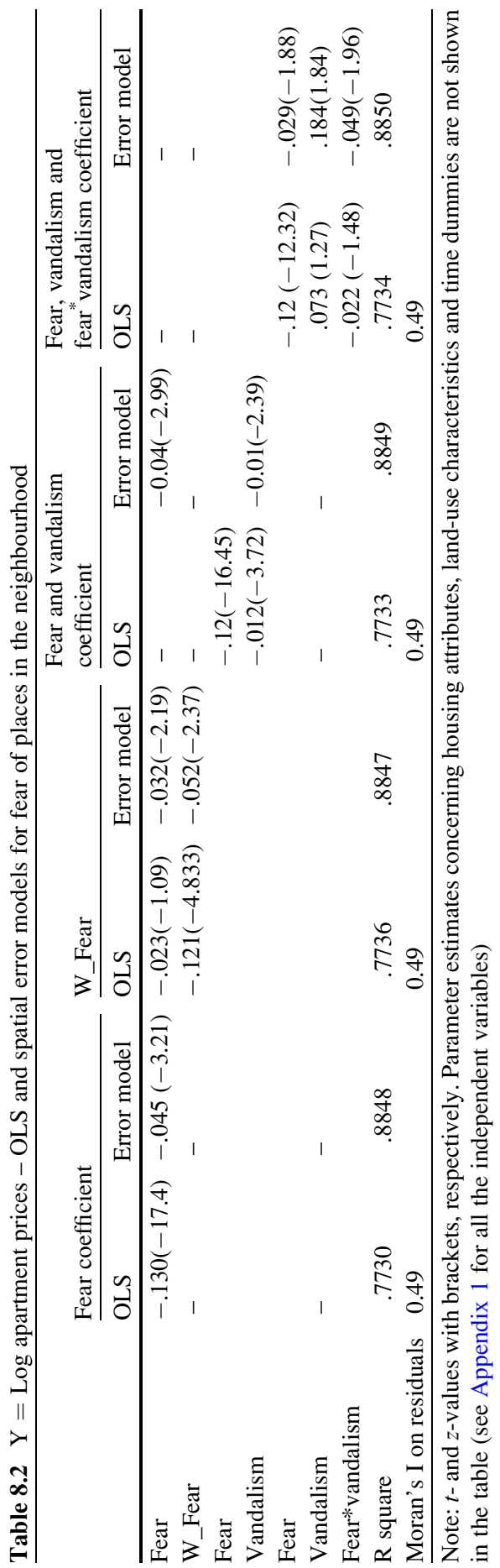


neighbourhood change instead. Gibbons (2004: 458) complements this reasoning, suggesting that if vandalism is seen as 'a predictor of neighbourhood decline and precursor of escalating crime rates', then it is not surprising that it impacts on housing values. In Stockholm, as in London, evidence shows that the vandalism is weakly to moderately associated with other crimes (the highest correlation is found between vandalism and theft from cars $r=.60$; for violence, the correlation is $r=.02$ ), suggesting that the link between disorder and crime may not necessarily be causal (see, e.g. Sampson and Raudenbush 1999).

Another explanation is that events of vandalism impact on apartment prices since they induce fear of crime. According to Killias and Clerici (2000), fear of crime is highly affected by graffiti, for example. In Stockholm, vandalism is the crime type that dominates police statistics followed by property crimes (38 per 1,000 inhabitants in Stockholm and 20 per 1,000 inhabitants in Sweden as a whole). According to the safety survey, around $8 \%$ of respondents have been victims of vandalism, as many as $60 \%$ declare that they perceive that vandalism (particularly graffiti) as a problem where they live and $70 \%$ think that littering is a major issue in their neighbourhood (Stockholm municipality 2008). If vandalism is perceived as a problem, it may also affect fear of crime.

New models were tested to assess whether fear of crime affects apartment prices, after controlling for vandalism and interaction effects between vandalism and fear of places in the neighbourhood (Table 8.2). The measure of fear of crime here relates to fear of places in the neighbourhood, which is a quite narrow and specific measure of fear of crime - adequate to test the effect at neighbourhood levels.

The explanation power of the fear model is almost the same as in the vandalism model in Table 8.1. Fear is negatively related to apartment price, and it also seems that fear in neighbouring areas is negatively related to prices. The latter is true in both the OLS and the error model. The difference between OLS and error estimates are much smaller in the fear model, indicating that the spatial structure is less correlated with the variable fear compared to the variable vandalism.

As previously stated, the results also indicate that apartment prices in a specific area are strongly affected by crime and/or fear of places in its neighbouring zones. Now the effect is negative on apartment prices regardless of the model analysed. There might be several different processes going on in neighbouring areas making it difficult to establish how they could affect buyers' perception. The negative impact on apartment prices in an area and its neighbouring zones may be related to spill-over processes (offenders act both where they live and in nearby areas, and people fear both where they live but also where they spend time, perhaps in nearby areas) but also copycat dynamics (e.g. if streets are littered, there is a chance that individuals assume that littering is acceptable, so the tendency is to find litter in other nearby streets too; in the end, this is bound to affect people's perception of these places).

So far, the results indicated that vandalism has an impact on apartment prices (not including fear in the model) and that fear has an impact (not including vandalism). The question is whether fear has an impact on prices controlling for vandalism or vice versa. 
The last model presented in Table 8.2 includes both the variables fear and vandalism and the interaction between them. There is some problem with multicollinearity between the variables fear and vandalism in the last model, but the results seem to suggest that the interaction model is the best model according to $R^{2}$ values. Interpretation of the estimates is slightly more complicated in a model including interaction variables. For example, our results suggest that fear has a negative impact but vandalism a positive impact on apartment prices. The interaction variable is negatively related to prices. A model not including the interaction variable indicates that both fear and vandalism are inversely related to price with a higher implicit price for fear than for vandalism. However, instead of interpreting the coefficient directly, we have calculated the marginal effect at mean values of fear and vandalism in the areas.

The overall results indicate that if fear and vandalism increase by $1 \%$, we expect that prices decrease on average $0.08 \%$. If fear increases by $10 \%$, price is expected to fall by $0.10 \%$ (when vandalism is kept constant), but if vandalism increases by $10 \%$ (given that fear is kept constant), apartment prices are anticipated to fall by $0.08 \%$. That is a slightly higher implicit price for fear. Moreover, the results also suggest that if vandalism increases, but fear remains the same, the change in reduction of apartment prices is rather small. On the other hand, if fear in an area increases for some reason, but the degree of vandalism remains the same, the change in reduction of prices is more substantial. In that respect, fear of places in the neighbourhood has a larger impact on apartment prices even if the effect is not independent of vandalism in the area.

In those areas where both occur, apartment values tend to be lower than in areas where either vandalism alone or fear affects property values. The trigger seems to be property damage, regardless of whether or not it is an indication of more serious crimes. For those living in these areas, littering and vandalism might indicate that no one is in control in the area and that social cohesion is lacking, which affect the way residents declare their own perceived safety. For those who are planning to buy a property in such areas, graffiti on walls, littering and unrepaired damage in the area, as suggested by Gibbons (2004: 458), 'is hard to conceal from prospective house purchasers. Whilst sellers may have private information about local incidents of other crimes - by personal victimisation, word of mouth or Neighbourhood Watch newsletters - this information is most likely unavailable to prospective home-buyers', and it is probably this first impression that sticks in people's minds and is the basis for price negotiation.

\subsection{Final Considerations}

The objective of this study was to assess whether lack of safety in neighbourhoods (potentially triggered by vandalism and/or fear of crime) affects property prices using data on about 9,000 apartment sales in Stockholm in 2008. Hedonic pricing modelling was employed to estimate the impact of vandalism and fear of crime controlling for 
other factors (property-related characteristics, place features, neighbourhood characteristics). Endogeneity was dealt with by including an instrument variable in the model. One of the novelties of the study was the use of environmental covariates produced using geographic information systems (GIS), such as distance bands from roads and parks. GIS also allowed the incorporation of the neighbourhood structure of crime data into the models, so the effect of vandalism and fear of places in neighbouring zones on apartment prices at a location could be tested.

Findings show that vandalism impacts negatively on apartment prices after controlling for attributes of the property and neighbourhood characteristics. Also, areas with depleted perceived safety are the ones with lower housing prices after controlling for other factors (property-related characteristics, place features, neighbourhood characteristics). When vandalism and fear of places in the neighbourhood are assessed together, results show housing values tend to be lower than in areas where either vandalism alone or fear affects property values. There is indication of a synergic effect of vandalism and fear in neighbourhoods that already show indications of decay.

Vandalism is an important factor motivating fear of crime in the community, even though the evidence here suggests that vandalism in Stockholm is not strongly correlated with incidents of a more serious nature, such as violence.

The mechanisms linking vandalism to fear of places in the neighbourhood can also be linked to the Wilson and Kelling's broken window syndrome (Wilson and Kelling 1982), which suggests that unrepaired damage to property encourages further vandalism and other types of crimes. Since no strong correlation was found with other crimes in Stockholm, it is believed there are other factors affecting the vandalism-fear link. First, there are indications that in areas where vandalism is the only problem, vandalism alone is not enough to affect people's perception of safety and pull the prices down. Second, vandalism is not reported to the police as consistently as more serious crimes are because it is regarded as a minor offence. Vandalism can also be underreported in areas with low social cohesion since residents do not bother to report minor offences to the police (Hirschfield and Bowers 1997), or where there is an overall mistrust in society's institutions (Ceccato and Lukyte 2011).

In support of the initial hypotheses, the price of an apartment is dependent on the fear of places in the neighbourhood as well as fear of places perceived in the surro unding areas. The direction of the impact of vandalism rates on prices is less conclusive. Findings presented so far are consistent with the assertion made by Pace and Gilley (1997) that certain spatial patterns within a market are large scale, and some small scale, and therefore their effects should be expected beyond a certain location. Future research should explore why factors affecting housing prices vary at various scales whilst others are more localised and also the reasons their effects differ over space (positively in certain areas, negatively in others).

What does this study tell us about the impact of crime and fear on neighbourhoods? Crime and fear of crime in neighbourhoods diminish apartment prices, resulting in lost property tax revenue and, more directly, quality of life of residents in general. For urban planners, police and other actors involved in crime prevention, 
having detailed geographical knowledge of a city's criminogenic conditions and its effects is important. From a physical planning point of view, if a place is highly targeted by crime or is perceived as unsafe, questions can be asked about the nature of that area, the activities that it attracts and how crime prevention practices can be re-organised to improve that area. For home insurance companies, there is a high value in knowing that crime affects housing prices and that this effect may vary geographically over a city and/or between them. Bank loans might use these results to predict levels of mortgage in different parts of the city and indirectly put pressure on local governments to act and plan for safer environments. The policy implications of these findings, however, are not clear. As suggested by Taylor (1995), if municipalities decide to increase taxes to pay for more public or private protection, this may induce owners to buy elsewhere. This cost imposed to increase safety may in turn outweigh the benefit of increased tax revenue from higher priced housing in safer neighbourhoods.

The current study is not without its limitations. First, it remains to be tested whether estimates on apartment prices will substantially diminish as other features of neighbourhoods are controlled. Of particular relevance, is residents' perceived quality of basic services, their attachment to the area (see, e.g. USK 2003) and their involvement in local crime prevention initiatives. According to Nilsson (2007), intervention in an unsafe residential area in Stockholm in the form of crime prevention programmes has a positive effect on housing owners and society in general. Second, the measure of fear used in this chapter (fear of places in the neighbourhood) is a global measure of fear (it does not refer to any particular crime, Hale 1996), which might be regarded as vague and may overestimate the prevalence of fear of crime (Farrall et al. 1997). Research in the future should explore not only more specific measures of fear (fear of what, fear of whom, whose fears) but also, as suggested by Farrall et al. (1997), time, space and social contexts when measuring fear of crime. Third, this is a crosssectional analysis, so it does not assess changes in crime levels or fear of crime on housing prices. Future studies should deal with changes in vandalism rates or fear of crime in the neighbourhoods because it may be that such changes, particularly the rapid ones, are more likely to affect apartment prices than the actual levels of crime. Neighbourhoods that experience rapid increases of crime and fear would likely show the highest effect on property prices. This effect should be assessed differently for different types of offences. This chapter, although the analysis is limited to vandalism, contributes to the evidence between the combined effects of property damage and fear of crime on apartment prices, something that until now has been lacking in the international literature. 


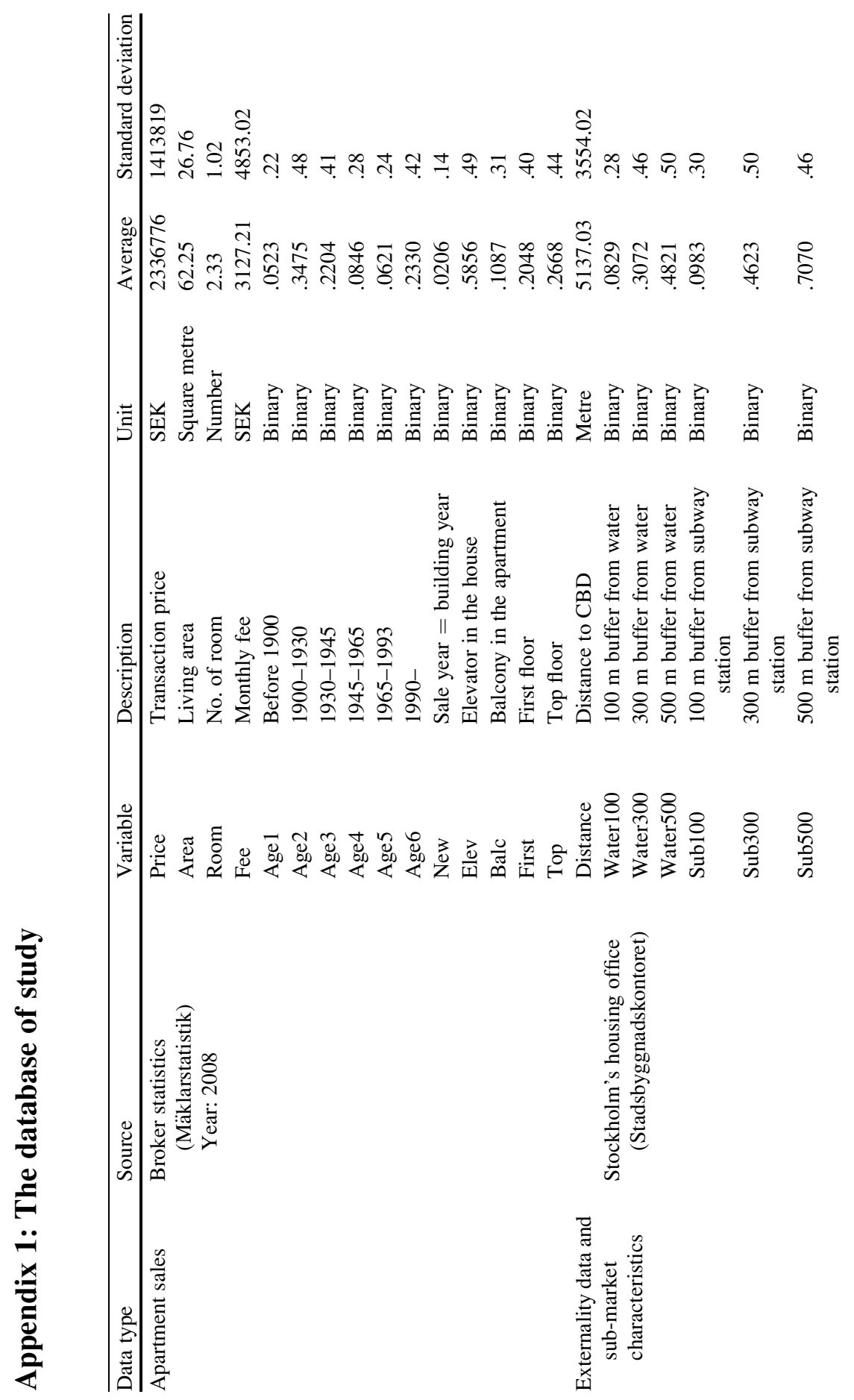




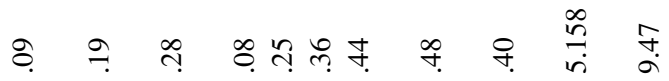

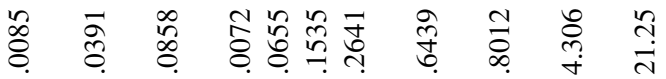

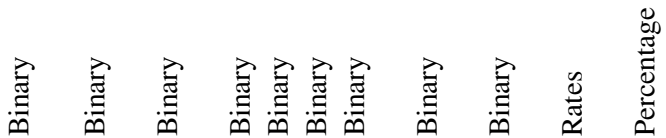

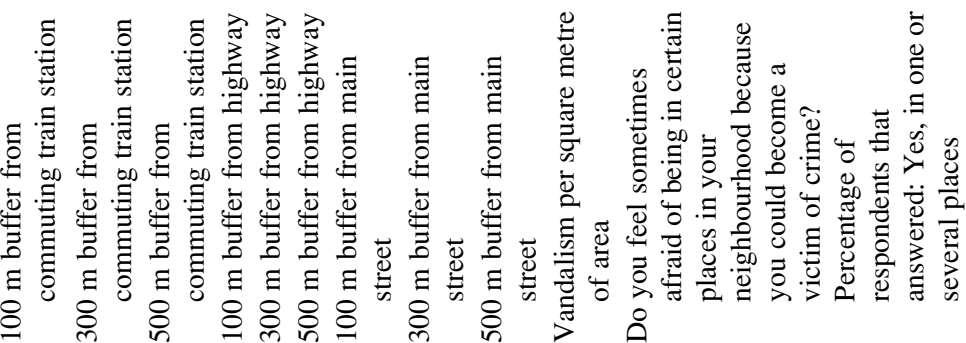

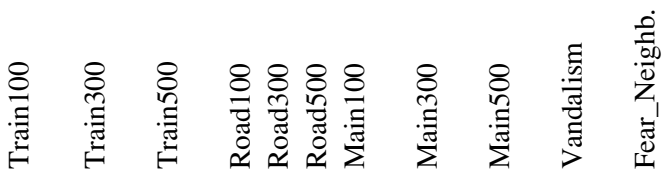

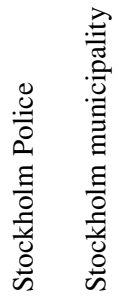

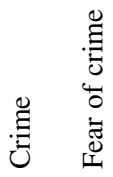




\section{References}

Anselin, L. (2003). GeoDa ${ }^{\mathrm{TM}}$ 0.9.3 user's guide. Spatial Analysis Laboratory, Department of Agricultural and Consumer Economics, University of Illinois, Urbana- Champaign, Urbana.

Bound, J., Jaeger, D. A., \& Baker, R. M. (1995). Problems with instrument variables estimation when correlation between instruments and the endogenous explanatory variable is weak. Journal of the American Statistical Association, 40(430), 443-450.

Bowes, D., \& Ihlanfeldt, D. (2001). Identifying the effects of rail stations on residential property values. Journal of Urban Economics, 50(1), 1-25.

BRÅ - Swedish National Council for Crime Prevention. (2010). Skadegörelse. http://www.bra.se/ extra/pod/?action=pod_show\&id=15\&module_instance=2 Assessed 3 Dec 2010.

Brantingham, P., \& Brantingham, P. (1995). Criminality of place: Crime generators and crime attractors. European Journal on Criminal Policy and Research, 3(3), 1-26.

Buck, A. J., Hakim, S., \& Spiegel, U. (1991). Casinos, crime, and real estate values: Do they relate? Journal of Research in Crime and Delinquency, 28(3), 288-303.

Caldeira, T. P. R. (2000). City of walls: Crime, segregation and citizenship in São Paulo. Berkeley: University of California Press.

Can, A. (1990). The measurement of neighborhood dynamics in urban house prices. Economic Geography, 66(3), 254-272.

Ceccato, V., \& Haining, R. (2005). Assessing the geography of vandalism: Evidence from a Swedish city. Urban Studies, 42(9), 1637-1656.

Ceccato, V., \& Lukyte, N. (2011). Safety and sustainability in a city in transition: The case of Vilnius, Lithuania. Cities, 28(1), 83-94.

Ceccato, V., \& Wilhelmsson, M. (2011). The impact of crime on apartment prices: Evidence from Stockholm, Sweden. Geografiska Annaler: Series B, Human Geography, 93(1), 81-103.

Ceccato, V., Haining, R., \& Signoretta, P. (2002). Exploring crime statistics in Stockholm using spatial analysis tools. Annals of the Association of American Geographers, 22(1), 29-51.

Clark, D. E., \& Cosgrove, J. C. (1990). Hedonic demand, identification, and the demand for public safety. Journal of Regional Science, 30(1), 105-121.

Cohen, S. (1973). Property reduction: Motives and meanings. In C. Ward (Ed.), Vandalism (pp. 23-53). New York: Van Nostrand Reinhold.

Cohen, M. A. (1990). A note on the cost of crime to victims. Urban Studies, 27(1), 139-146.

Day, K. (2009). Being feared: Masculinity and race in public space. In M. Lee \& S. Farral (Eds.), Fear of crime: Critical voices in an age of anxiety (pp. 82-107). New York: RoutledgeCavendish.

Del Frate, A. A., \& Van Kesteren, J. N. (2004). Criminal victimisation in urban Europe. Key findings of the 2000 international crime victims survey. Turin: UNICRI.

Dubin, R. A., \& Goodman, A. C. (1982). Valuation of education and crime neighborhood characteristics through hedonic housing prices. Population and Environment, 5(3), 166-181.

Eschholz, S. (1997). The media and fear of crime: A survey of the research. Journal of Law and Public Policy, 9(3), 37-59.

Eyler, A. A., Baker, E., Cromer, L., King, A. C., Brownson, R. C., \& Donatelle, R. J. (1998). Physical activity and minority women: A qualitative study. Health Education \& Behavior, 25(5), 640-652.

Farrall, S., Bannister, J., Ditton, J., \& Gilchrist, E. (1997). Questioning the measurement of the "fear of crime". British Journal of Criminology, 37(4), 658-679.

Ferraro, K. F. (1995). Fear of crime: Interpreting victimization risk. Albany: State University of New York Press.

Foster, S., \& Giles-Corti, B. (2008). The built environment, neighborhood crime and constrained physical activity: An exploration of inconsistent findings. Preventive Medicine, 47(3), 241-251. 
Fransson, U., Rosenqvist, G., \& Turner, B. (2002). Hushallens värdering av egenskaper i bostäder och bostadsomraden (Forskningsrapport 2002:1). Gävle: Institutet för bostads-och urbanforskning, Uppsala Universitet.

Garcia, R. M., Taylor, R. B., \& Lawton, B. A. (2007). Impacts of violent crime and neighborhood structure on trusting your neighbors. Justice Quarterly, 24(4), 679-704.

Gibbons, S. (2004). The costs of urban property crime. The Economic Journal, 114(499), F441-F463.

Hale, C. (1996). Fear of crime: A review of the literature. International Review of Victimology, $4,79-150$.

Hellman, D. A., \& Naroff, J. L. (1979). The impact of crime on urban residential property values. Urban Studies, 16(1), 105-112.

Hirschfield, A., \& Bowers, K. J. (1997). The effect of social cohesion on levels of recorded crime in disadvantaged areas. Urban Studies, 34(8), 1275-1295.

Jackson, J., \& Gray, E. (2010). Functional fear and public insecurities about crime. British Journal of Criminology, 50(1), 1-22.

Karlsson, V. (2008). The relationship between housing prices and transport improvements: A comparison of metropolitan and rural areas in a large but thinly populated European country. Bifröst Journal of Social Science, 2, 141-166.

Killias, M., \& Clerici, C. (2000). Different measures of vulnerability in their relation to different dimensions of fear of crime. British Journal of Criminology, 40(3), 437-450.

Kornhauser, R. (1978). Social sources of delinquency. Chicago: University of Chicago Press.

Kryvobokov, M., \& Wilhelmsson, M. (2007). Analysing location attributes with a hedonic model for apartment prices in Donetsk, Ukraine. International Journal of Strategic Property Management, 11, 157-178.

LaGrange, R. L., \& Ferraro, K. F. (1989). Assessing age and gender differences in perceived risk and fear of crime. Criminology, 27(3), 697-719.

Landman, K. (2005). The storm that rocks the boat: The systemic impact of gated communities on urban sustainability. Cybergeo: European Journal of Geography, Dossiers, Systemic impacts and sustainability of gated enclaves in the City, Pretoria, South Africa http://cybergeo.revues. org/index11133.html. Assessed 20 Feb 2011.

Larsen, J. E., Lowrey, K. J., \& Coleman, J. W. (2003). The effect of proximity to a registered sex offender's residence on single-family house selling price. The Appraisal Journal, 71(3), 253-265.

Lewis, D. A., \& Maxfield, M. G. (1980). Fear in the neighborhoods: An investigation of the impact of crime. Journal of Research in Crime and Delinquency, 17(2), 160-189.

Linden, L. \& Rockoff, J. (2006). There goes the neighborhood? Estimates of the impact of crime risk on property values from Megan's laws. National Bureau of Economic Research (Working Paper, No. 12253).

Los, M. (2002). Post-communist fear of crime and the commercialisation of security. Theoretical Criminology, 6(2), 165-188.

Lynch, A. K., \& Rasmussen, D. W. (2001). Measuring the impact of crime on house prices. Applied Economics, 33(15), 1981-1989.

Magnusson, L., \& Berger, T. (1996). Hyressättning på de boendes villkor. Gävle: Meyers.

McCrea, R., Shyy, T., Western, J., \& Stimson, R. J. (2005). Fear of crime in Brisbane: Individual, social and neighbourhood factors in perspective. Journal of Sociology, 41(1), 7-27.

Miles, R., \& Panton, L. (2006). The influence of the perceived quality of community environments on low-income women's efforts to walk more. Journal of Community Health, 31(5), 379-392.

Ministry of Justice. (1999). The Swedish penal code, 36. Stockholm: Regeringskansliet.

Munroe, D. K. (2007). Exploring the determinants of spatial pattern in residential land markets: Amenities and disamenities in Charlotte, NC, USA. Environment and Planning B Planning and Design, 34(2), 336-354.

Murray, L. (2007). Inventing fear of crime: Criminology and the politics of anxiety. Portland: Willan Publishing. 
Nilsson, J. (2007). Ekonomiska effekter av trygghetsaitgärder i bostadsomraiden. Master thesis at the Department of Department of Real Estate and Construction Management, Royal Institute of Technology, 404: 52. http://www.infra.kth.se/se/byfa/publikationer/examensarbeten/2007/ 404.pdf. Assessed 23 Dec 2010.

Pace, R. K., \& Gilley, O. W. (1997). Using the spatial configuration of the data to improve estimation. Journal of Real Estate Finance and Economics, 14(3), 333-340.

Pain, R. (2000). Place, social relations and the fear of crime: A review. Progress in Human Geography, 24(3), 365-387.

Pain, R. (2009). Globalized fear? Towards an emotional geopolitics. Progress in Human Geography, 33(4), 466-486.

Pain, R. (2010). The new geopolitics of fear. Geography Compass, 4(3), 226-240.

Pope, J. C. (2008). Fear of crime and housing prices: Household reactions to sex offender registries. Journal of Urban Economics, 64(3), 601-614.

Riger, S., LeBailly, R. T., \& Gordon, M. T. (1981). Community ties and urbanites' fear of crime: An ecological investigation. American Journal of Community Psychology, 9(6), 653-665.

Rizzo, M. J. (1979). The effect of crime on residential rents and property values. The American Economist, 23(1), 16-21.

Rosen, S. (1974). Hedonic prices and implicit markets: Product differentiation in pure competition. Journal of Political Economy, 82(1), 34-55.

Ross, C. E. (1993). Fear of victimization and health. Journal of Quantitative Criminology, 9(2), $159-175$.

Sampson, R. J., \& Raudenbush, S. W. (1999). Systematic social observation of public spaces: A new look at disorder in urban neighbourhoods. The American Journal of Sociology, 105(3), 603-651.

Sampson, R. J., Raudenbush, S. W., \& Felton, E. (1997). Neighbourhoods and violent crime: A multilevel study of collective efficacy. Science, 277(5328), 918-924.

SCB - Statistiska centralbyrån (Statistics Sweden). (2008) Standard of living survey: Question on vandalism.

Scheider, M. C., Rowell, T., \& Bezdikian, V. (2003). The impact of citizen perceptions of community policing on fear of crime: Findings from twelve cities. Policy Quarterly, 6, 363-386.

Shaw, C. R., \& McKay, H. D. (1942). Juvenile delinquency and urban areas. Chicago: University of Chicago Press.

Skogan, W. G. (1990). Disorder and decline: Crime and the spiral of decay in American neighborhoods. New York: Free Press.

Skogan, W. G. (1996). The police and public opinion in Britain. American Behavioral Scientist, 39 (4), 421-432.

Skogan, W., \& Maxfield, M. G. (1981). Coping with crime: Individual and neighbourhood reactions. Beverly Hills: Sage.

Stockholm Municipality. (2008). Trygg I Stockholm? 2008 En stadsövergripande trygghetsmätning. Stockholm, 43p.

Sundquist, K., Theobalda, H., Yangb, M., \& Lia, X. (2006). Neighborhood violent crime and unemployment increase the risk of coronary heart disease: A multilevel study in an urban setting. Social Science \& Medicine, 62(8), 2061-2071.

Taylor, R. B. (1995). The impact of crime on communities. The Annals of the American Academy of Political and Social Science, 539(1), 28-45.

Thaler, R. (1978). A note on the value of crime control: Evidence from the property market. Journal of Urban Economics, 5(1), 137-145.

Tita, G. E., Petras, T. L., \& Greenbaum, R. T. (2006). Crime and residential choice: A neighborhood level analysis of the impact of crime on housing prices. Journal of Quantitative Criminology, 22(4), 299-317.

Torstensson, M. (1994). Brott och ordningsstorningar i butiker. Stockholm: Brottsforebyggande radet. 
USK - Utrednings - och StatistikKontoret, (2003). Situation och service $i$ stadsledelen 2002-Sa tycker brukarna, jämförelser med 1996 och 1999. Stockholm: Stockholmstad.

Wikström, P.-O. H. (1991). Urban crime, criminals, and victims: The Swedish experience in an Anglo-American comparative perspective. Stockholm: Springer.

Wilhelmsson, M. (2002). Spatial models in real estate economics. Housing, Theory and Society, $19,92-101$.

Will, J. A., \& Mcgrath, J. H. (1995). Crime, neighbourhood perceptions and the underclass: The relationship between fear of crime and class position. Journal of Criminal Justice, 23(2), $163-176$.

Wilson, J. Q., \& Kelling, G. (1982). The police and neighborhood safety: Broken windows. Atlantic, 127, 29-38.

Wyant, B. R. (2008). Multilevel impacts of perceived incivilities and perceptions of crime risk on fear of crime. Journal of Research in Crime and Delinquency, 45(1), 39-64.

Zelinka, A., \& Brennan, D. (2001). Safescape. Chicago: American Planning Association. 